International Journal of Social Sciences and Humanities
Available online at http://sciencescholar.us/journal/index.php/ijssh
Vol. 2 No. 2, August 2018, pages: 115 123
e-ISSN: 2550-7001, p-ISSN: 2550-701X
https://doi.org/10.29332/ijssh.v2n2.150

\title{
Interpersonal Society of Satria Dalem
}

Ida Bagus Brata ${ }^{a}$, A.A. Gde Putra Pemayun b

Article history: Received 9 January 2018, Accepted in revised form 1 June 2018, Approved 20 July 2018, Available online 27 July 2018

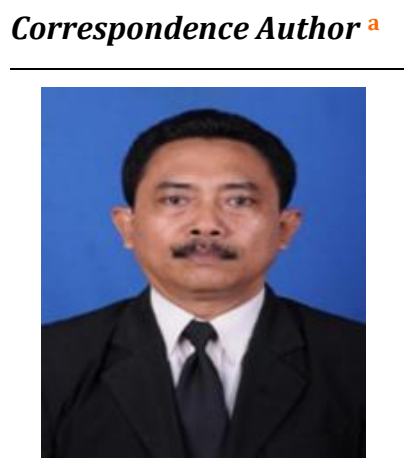

Keywords

Community members; Interpersonal society; Satria dalem; Self-concept; Society;

\begin{abstract}
This study examines "Interpersonal Society between offspring of satria dalem with the community in Tohpati Village Klungkung Bali. Interpersonal Society Skill is a skill that individuals must take in interacting with individuals in interacting with other individuals or groups of individuals (Goldstein, 2008). Interpersonal skills are what one uses when communicating and dealing with others face to face (Rachmat, 2011). Society implies that society is essential for building self-concept, for survival, self-actualization, to gain happiness, avoiding stress and dependence, among others through entertaining society, and fostering relationships. Through social society can work together with community members (families, study groups, universities, village environment, city, and the country as a whole) to achieve common goals. Problems in this research: how to implement interpersonal society between offspring satria dalem with society in Tohpati Village Klungkung Bali. The purpose of this research is to know and describe interpersonal society within the community in Tohpati Village Klungkung Bali. This research uses the descriptive qualitative method, by using proportional sampling technique consisting of the family head of satria dalem with the society in Tohpati Village Klungkung Bali. The results of this study show that the people of satria dalem descent and the people who live in Tohpati Village have implemented good interpersonal society implementation including: openness, mutual support, positive behavior, empathy and equality, it is proven that all citizens are united in advancing Tohpati Village Klungkung Bali, proven human development index is increasing due to mutual trust, there is togetherness, warmth, comfort feel valued in doing their respective tasks to build the forward Tohpati Village Klungkung.
\end{abstract}

e-ISSN : 2550-7001, p-ISSN : 2550-701X ${ }^{\odot}$ Copyright 2018. The Author. SS Journals Published by Universidad Técnica de Manabí. This is an open-access article under the CC BY-SA 4.0 license

(https://creativecommons.org/licenses/by-sa/4.0/) All rights reserved.

a Vice Dean III in FKIP. Mahasaraswati University, Denpasar, Indonesia

b Department of Economics, Faculty of Economics Undiknas University, Denpasar, Indonesia 


\section{Contents}

Abstract

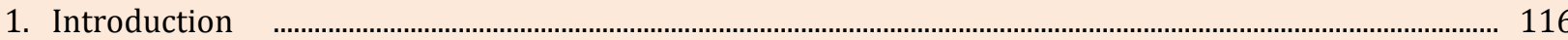

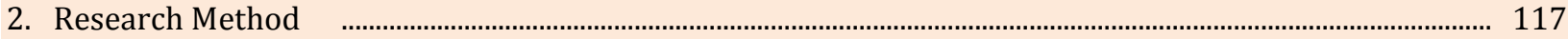

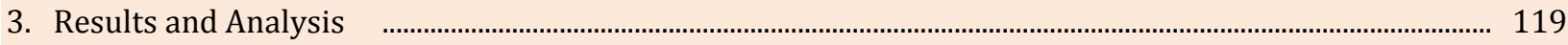

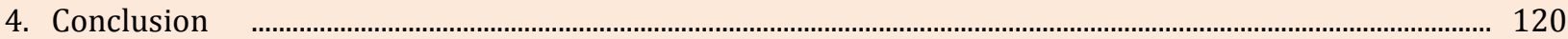

Conflict of interest statement and funding sources........................................................................................ 121

Statement of authorship ............................................................................................................................................. 121

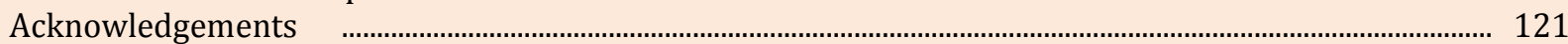

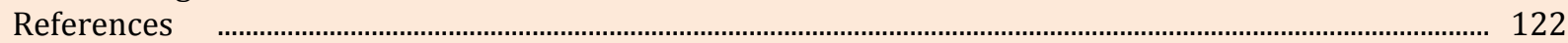

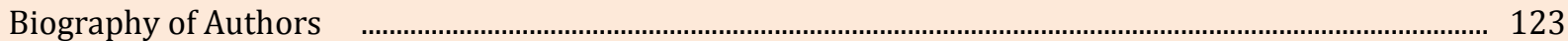

\section{Introduction}

In life, people are always involved in social activities. Contextually, interpersonal society is described as a society between two individuals or few individuals, which interact with each other, giving each other feedback. Therefore society is a human action that is born with full awareness, even actively human beings born because there is a purpose or a particular purpose. Interpersonal society is the process of exchanging information between someone with at least one other person or usually between two people who can be directly known backward (Arni, 2009). Based on preliminary research that in the life of society is a major requirement in human life. No human is releasing his life to communicate with each other. Therefore, social society is very important in human life, in general, to help him interact with others, because humans are created as social beings.

People who never communicate with others will certainly get lost because he did not have time to organize himself in a social environment. A society that enables an individual to build a frame of reference and use it as a guide for interpreting, whatever situations it faces. The society also allows him to learn and implement adaptive strategies to address problematic situations that may occur.

\section{Literature Review}

Case studies of interpersonal society between community groups in the country have been widely studied by both local and foreign researchers. However, the special research of interpersonal society between offspring of satria dalem and the community in Tohpati Village Klungkung Bali is interesting to be studied because there has not been raised as a research to obtain research findings. Based on the study of studies on interpersonal society in Indonesia examined by Euis Nurul Bahriyah (2012) entitled "Interpersonal Society Tour Guide in Introducing Indonesia to Foreign Travelers". The results of this study describe that interpersonal society can provide a sense of comfort to foreign tourists who visit Indonesia with a wonderful guide Indonesia, the tourists want to travel in accordance with the budget that is owned and the ease of all tourism destinations Indonesia. Also, Mira Juwita Surya Ningrum's research (2014) entitled "Perception of Social Support and Interpersonal Society Ability in Lung Tuberculosis Patients in Denpasar". In it is described interpersonal society often experience obstacles, caused by a disease, such as pulmonary tuberculosis. Pulmonary tuberculosis is a contagious disease directly caused by the bacteria Mycobacterium tuberculosis. Pulmonary tuberculosis patients experience anxiety, fear, and embarrassment that inhibit interpersonal society, where patients with Pulmonary Tuberculosis are difficult to communicate what is felt and thought about the disease experienced. One handling is social support, to reduce anxiety, fear, shame to others. Thus, the focus of the study of interpersonal society is often constrained, caused by a disease for which social support is potential as a cure. While this research raised the title of Interpersonal Society between descendants satria dalem with the community in the Tohpati Village Klungkung Bali as a study of interpersonal society today. 


\section{Research Methods}

\section{Types and Data Sources}

The data used in this research are:

a) Primary data, ie data, and information obtained directly from sources/respondents. This data was obtained by interviewing the descendants of satria dalem and the people living in Tohpati Village Klungkung Bali. By using proportional sampling technique with a sample of 7 people from offspring of satria dalem and 25 people.

b) Secondary data, namely data and supporting information obtained from the Tohpati Village Klungkung Bali office.

\section{Specification of the research model}

The Social Exchange Theory John Thibaut and Peter Blau (2009) The theory of social exchange states that society is put into exchange relations with others, therefore, earned a reward. In other words, the exchange relationship between offspring of satria dalem and the Tohpati Villagers Klungkung will result in a compensation in return for the parties they expect as a community of rural communities as a symbol of togetherness. The theory of social exchange is a theory in social science that states that in social relations there are elements of reward, sacrifice, and mutual advantage.

The Social Category Theory Melvin L. De Fleur (2010) Social category theory is a collection, group, or social categories that exist in society will provide a uniform response to media exposure. This theory states that there are associations such as the descendants of the knights and the other communities in the Tohpati Village Klungkung, the social category in the urban-industrial society whose behavior when hit by certain incentives will be almost uniform. The basic assumption of social category theory is the sociological theory which states that although the life of modern society is heterogeneous, people who possess some of the same features will have the same traditional lifestyle. Characteristics: age, sex, income, education, settlement or religious affiliation. The equation of style, orientation and behavior will be related to a phenomenon as in mass media in a uniform behavior.

\section{Research Location}

The location of this research is in Tohpati Village Klungkung Bali by observing and mapping the measured activity of the community. The observation time as an object of analysis is a 12 (twelve) month period from January to December running in 2017. 2017 usage considerations are taken to facilitate the recording of information to respondents, i.e., offspring of satria dalem and the community in Tohpati Village Klungkung Bali.

\section{Research Instruments}

The instrument used in this research is descriptive research through literature survey and field survey and in-depth interview. The interviews were open-ended questions and closed-ended questions.

\section{Data Analysis Method}

The method of analysis used in this study include several methods in accordance with the objectives of the study are as follows:

a) The Social Exchange Theory of John Thibaut and Peter Blau (2009). The social exchange theory states that society is put into exchange relations with others, therefore, earned rewards. In other words, the exchange relationship between offspring of satria dalem and the Tohpati Villagers Klungkung will result in a compensation in return for the parties they expect as a community of rural communities as a symbol of togetherness. The theory of social exchange is a theory in social science that states that in social relations

Brata, I. B., \& Pemayun, A. G. P. (2018). Interpersonal society of Satria Dalem. International Journal of Social Sciences and Humanities, 2(2), 115-123. https://doi.org/10.29332/ijssh.v2n2.150 
there are elements of reward, sacrifice, and mutual advantage. This theory explains how the community of nobles with the surrounding community perceives a mutually beneficial relationship in accordance with the assumption that the balance between what is given into the relationship and what is excluded from the relationship, the type of relationship it has, the chance of having a better relationship with the person other. The point of view of social exchange states that one calculates the overall value of a relationship by subtracting its sacrifice from the reward received (Monge, 2009). The assumptions of the theory of social exchange on the basic nature of the satria society are as follows: the descendants of the knights and the surrounding community achieve an award and avoid punishment. The idea that human beings seek rewards and avoid punishment according to the conceptualization of reduction of impulse (Roloff, 2011). This approach suggests that people's behavior is motivated by an internal drive mechanism. When people feel this urge, they are motivated to reduce it, and the process of execution is fun. That man as a rational being is an important assumption for the theory of social exchange. The standards that humans use to evaluate sacrifices and rewards vary over time and from one person to another. The third assumption, indicating that this theory should consider the existence of diversity. There is no one standard that anyone can use to determine what the sacrifices and rewards are. The assumptions made by the social exchange theory about the nature of a relationship: (1) Relationships have the nature of interdependence, in a relationship when a participant takes an action, either one participant or their relationship as a whole will be affected. (2) Relative life is a process. The importance of time and change in the life of a relationship. In particular, time affects the exchange because past experiences guide judgments about rewards and sacrifices, and this judgment affects subsequent exchanges.

b) Social Category Theory Melvin L. De Fleur (2010). Social category theory is a collection, group, or social categories that exist in society will provide a uniform response to media exposure. This theory states that there are associations such as the descendants of the knights and community in the Tohpati Village Klungkung, the social category of the urban-industrial society whose behavior when exposed to certain incentives will be almost uniform. The basic assumption of social category theory is the sociological theory which states that although the life of modern society is heterogeneous, people who possess some of the same features will have the same traditional lifestyle. Characteristics: age, sex, income, education, settlement or religious affiliation. The equation of style, orientation and behavior will be related to a phenomenon as in mass media in a uniform behavior. Members of a particular category will choose about the same society, and respond in almost the same way. This theory is consistent that comes from the general sociology of the mass media. The relationship between mass society and interpersonal society can be seen in the socialization effect of the mass media. Mass media is one source where people learn about the people who live in the long span of time will occur acculturation each culture that forms a new culture of the community. In this case, the mass media influences the way society relates to each other on an interpersonal level. Elements of the concept of self-awareness in social interaction between human beings such as (1) Self-concept, that is how to look at yourself, usually, this is done by the classification of personal characteristics, characteristics of social properties, and social role. (2) at least in the perception of self. These characteristics can be physical (male, female, tall, low, beautiful, handsome, plump) or can also refer to certain abilities (clever, quiet, capable, ignorant, educated) self-concept is closely related to knowledge. If one's knowledge is high then one's self-concept is high too. On the other hand, if one's knowledge is low then one's self-concept is low too. (3) Social characteristics ie attributes displayed in relation to others (gracious or curt, extrovert or introvert, talkative or quiet, caring or careless).

\section{Observation Techniques and Interviews}

Observation is done by observation directly in the field so that it can see and observe more carefully about the condition of Tohpati Village Klungkung Bali. In-depth interviews (In-depth Interview) with some informants who have set 32 people.

\section{Documentation Study}

Documentation study is data collection techniques by taking some documents or past records in the village office and relevant agencies. 


\section{Results and Analysis}

a) The Social Exchange Theory John Thibaut and Peter Blau (2009) Interpersonal society is a society that only two people, such as husband and wife, two colleagues, two close friends, teacher-students and so forth, (Mulyana, 2010). So it can be said that interpersonal society is the process of delivering information, thoughts, and attitudes between the descendants of satria dalem with the components of society in the Tohpati Village Klungkung there is a change of message both as communicant and communicator with the aim to achieve mutual understanding, about the problem to be discussed which eventually expected behavior change occurs. Communities are put into exchange relationships with others, therefore, earned rewards. In other words, the community exchange relationship with satria dalem community in Tohpati Village Klungkung Bali will result in a compensation for all components of society in accordance with their respective work. The theory of social exchange is a theory in social science is stated that in social relations there are elements of rewards, sacrifices, and mutual benefits. Described how the community of satria dalem descendants with the community in the Tohpati Village Klungkung of Bali sees a mutually beneficial relationship in accordance with the assumption that the balance between what is given into the relationship and what is excluded from the relationship, the type of relationship, the possibility of having more relationship good with others. The point of view of social exchange states that one calculates the overall value of a relationship by subtracting its sacrifice from the reward received (Monge, 2009). Success in conveying information is largely determined by the nature and quality of the relationships among the persons involved and contains the five general qualities considered: openness, the quality of openness refers to at least three aspects of interpersonal society. First, effective interpersonal communicators must be open to the person to whom they interact. This does not mean that one has to disclose all history about his life but there must be a willingness to disclose information normally concealed, provided that this selfdisclosure is appropriate. The second refers to the willingness of communicators to react honestly to the stimulus that comes. The third aspect concerns the ownership of feelings and thoughts. It is open to acknowledging that the feelings and thoughts that people throw are indeed theirs and must be accounted for. Empathy (empathy), as a person's ability to know what is being experienced by others at a certain moment, from the other person's point of view. People who are empathetic are able to understand the motivations and experiences of others, their feelings and attitudes, and their hopes and desires in the future. This empathetic understanding will make a person more able to adjust his society, (Devito in Rakhmat, 2010). Supportive attitude (supportiveness), the effective interpersonal relationship is a relationship where there is a supportive attitude (supportive). Supportive attitude is characterized by (1) descriptive attitude, is perceiving a society as a request for information or description about a certain occurrence and do not feel it as a threat. (2) the spontaneous, spontaneous person in his society and openly expressed his thoughts usually receives the same reaction and (3) provisional, meaning being tentative and open-minded and willing to hear opposing views and willing to change positions if circumstances require them. When a person is convinced unshakable and closed-minded, it will encourage the defensive behavior of the listener.

Positive attitude (Positiveness), positive attitude in interpersonal society there are two ways: (1) expressed positive attitude refers to at least two aspects of interpersonal society. First, interpersonal society is constructed if people have a positive attitude toward themselves, and Second positively encourages the person who is the friend to interact and equality, interpersonal society is more effective when the atmosphere is equal, that is, there must be a tacit recognition that both parties are equally valuable and valuable, and that each side has something important to contribute. Effective society is characterized by good interpersonal or emotional relationships. Society failure occurs when the message content is understood, but the relationship between the communicant becomes damaged. When a person gathers in a group that has something in common with him, then that person will feel happy, and open. Conversely, when he is gathered with people he hates, then it will make him feel tense, restless, and uncomfortable. Thus a person will shut down and avoid society or want to immediately terminate the society (Devito in Rakhmat, 2010). From the above discussion can be said the theory of social exchange is a social relationship there are elements of rewards, sacrifices, and benefits that affect each other between heritage satria dalem with community communities in the Tohpati Village Klungkung. The exchange

Brata, I. B., \& Pemayun, A. G. P. (2018). Interpersonal society of Satria Dalem. International Journal of Social Sciences and Humanities, 2(2), 115-123. https://doi.org/10.29332/ijssh.v2n2.150 
relationship of the community of descendants of the satria dalem with the surrounding community in Tohpati Village Klungkung Bali will result in a compensation in return for the communities involved in accordance with the previous agreement.

b) The Social Category Theory Melvin L. De Fleur (2010). Social category theory is a collection, group, or social categories that exist in society will provide a uniform response to media exposure. The existence of associations, social categories in the urban-industrial society whose behavior when hit by certain incentives will be almost uniform. The relationship between mass society and interpersonal society is described as an intervening variable between mass media and behavioral changes that occur between satria dalem and societies in Tohpati Village Klungkung. Another connection between mass society and interpersonal society can be seen between the complementary roles between mass media channels and interpersonal society when one decides to accept or reject innovation. The relationship between mass society and interpersonal society can be seen in the socialization effect of the mass media. Mass media is one source where people learn about the surrounding community. In this case, the mass media influence the way the descendants of the satria dalem and the surrounding community communities relate to each other in the interpersonal level. Elements of the concept of self-awareness in social interaction between human beings such as (1) Self-concept, that is how to look at yourself, usually, this is done by the classification of personal characteristics, characteristics of social properties, and social role. (2) , at least in the perception of self. These characteristics can be physical (male, female, tall, low, beautiful, handsome, plump) or can also refer to certain abilities (clever, quiet, capable, ignorant, educated) self-concept is closely related to knowledge. If one's knowledge is high then one's self-concept is high too. On the other hand, if one's knowledge is low then one's self-concept is low too. (3) the social characteristic that is shown in relationship with others (friendly or curt, talkative or quiet, caring or careless, etc.). This affects the social role, ie everything that includes the relationship between offspring satria dalem with communities located in the Tohpati Village Klungkung. (4) The social role, when the social role is part of the selfconcept, then defined social relationships with others, such as father, wife, or teacher. This social role can also be related to culture, ethnicity, or religion. (5) Different selves (selves) between a person from a noble knight and a community living in the Tohpati Village Klungkung as he performs various activities, interests, and social relationships. When engaged in interpersonal society, it has two self-concepts, such as perceptions of self, and perceptions about others' perceptions of them. From the above discussion, it can be said that the basic assumption of social category theory that is a sociological theory which states that although community descendants satria dalem and social living in the Tohpati Village Klungkung modern Balinese heterogeneous nature, the population who has a number of characteristics that will have the same lifestyle the same traditional. Characteristics: age, sex, income, education, settlement or religious affiliation. The equation of style, orientation and behavior will be related to a phenomenon as in mass media in a uniform behavior. Members of a particular category will choose about the same society, and respond in almost the same way. This affects the social role, which is everything that includes the relationship between offspring of satria dalem with community communities located in the Tohpati Village Klungkung. This theory is consistent that comes from the general sociology of the mass media.

\section{Conclusion}

First, the theory of social exchange states that in social relations there are elements of rewards, sacrifices, and mutual benefits. The exchange relationship of the community of descendants of the satria dalem with the people living in Tohpati Village Klungkung Bali will result in a compensation reward for the communities involved. Secondly, the basic assumption of social category theory is a sociological theory which states that although the offspring of satria dalem and the people who live in Tohpati Village Modern Klungkung is heterogeneous, residents who possess a number of similar traits will have the same traditional lifestyle. The distinct identity of the self between the noble knights and the people who live in the Tohpati Village Klungkung as he performs various activities, interests, and social relationships. 
Conflict of interest statement and funding sources

The authors declared that they have no competing interest. The study was financed by personal funding.

Statement of authorship

The authors have a responsibility for the conception and design of the study. The authors have approved the final article.

Acknowledgments

The author would like to thank the editor of IJSSH for their support, advice, and valuable time.

Brata, I. B., \& Pemayun, A. G. P. (2018). Interpersonal society of Satria Dalem. International Journal of Social Sciences and Humanities, 2(2), 115-123. https://doi.org/10.29332/ijssh.v2n2.150 


\section{References}

1. Cangara, H. M., Ishida, T., Hara, T., Sun, L., Toh, R., Rikitake, Y., ... \& Hayashi, Y. (2010). Role of endothelial cell-selective adhesion molecule in hematogeneous metastasis. Microvascular research, 80(1), 133-141. View in (Google Scholar)

2. DeVito, J. A. (2010). The interviewing guidebook. Allyn and Bacon. View in (Google Scholar)

3. Enjang, A. S. (2009). Komunikasi Konseling. Bandung: Nuansa. View in (Google Scholar)

4. Hardjana, A. M. (2010). Konflik dalam Organisasi.

View in (Google Scholar)

5. Rakhmat, J. (2011). Psikologi Komunikasi, PT Remaja Rosdakarya, Bandung. Aw, Sunarto. View in (Google Scholar)

6. Maliki, Z. (2000). Agama rakyat, agama penguasa: konstruksi tentang realitas agama dan demokrasi. Yayasan Galang. View in (Google Scholar)

7. Robert, A. D., \& Byrne, D. (2005). Psikologi Sosial Jilid 1. Jakarta: Erlangga. View in (Google Scholar)

8. Supratiknya, A. (1995). Komunikasi antar pribadi, tinjauan psikologis. Kanisius. View in (Google Scholar)

9. Rahma, N. (2016). Komunikasi Terapeutik Perawat kepada Pasien di Puskesmas Antang Perumnas Makassar (Doctoral dissertation, Universitas Islam Negeri Alauddin Makassar). View in (Google Scholar)

10. Schramm, W. (1954). How society works. The process and effects of mass society, 3-26. View in (Google Scholar)

11. Cangara, H. (2000). Pengantar ilmu komunikasi. PT Rajagrafindo Persada. View in (Google Scholar)

12. Meza, A. K. T., Freyre, J. R. A., Cevallos, M. G. O., \& Pico, M. J. M. (2018). Autonomy, Good Humor and Support Networks, Potential of Community Resilience Intervention in People Victims of the Earthquake in the Calderón Parish. International Research Journal of Management, IT and Social Sciences (IRJMIS), 5(1), 1-8. View in (Google Scholar)

13. García, B. B. B., Cedeño, H. A. C., Chica, T. K. M., \& Ríos, Y. R. P. (2018). Characterization of Auditory Disability and Its Relation to the Resilience. International Research Journal of Management, IT and Social Sciences (IRJMIS), 5(2), 15-22.

View in (Google Scholar)

14. Suarta, I. M. (2017). Revitalization of Oral Literature Tradition of Balinese Society Based Character Values As Deradicalism Effort. International Journal of Social Sciences and Humanities (IJSSH), 1(3), 8-16.

View in (Google Scholar) 


\section{Biography of Authors}

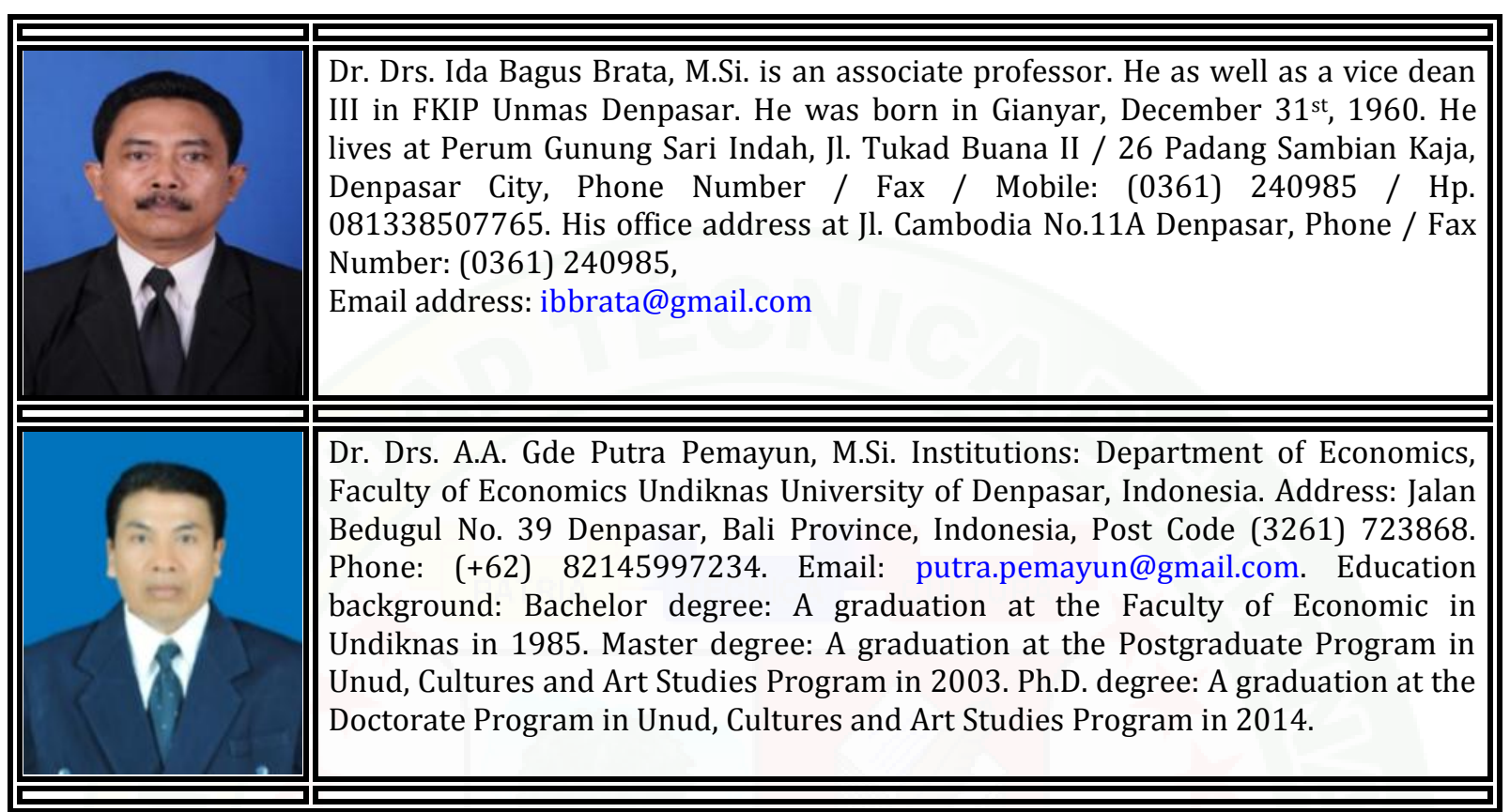

Brata, I. B., \& Pemayun, A. G. P. (2018). Interpersonal society of Satria Dalem. International Journal of Social Sciences and Humanities, 2(2), 115-123. https://doi.org/10.29332/ijssh.v2n2.150 